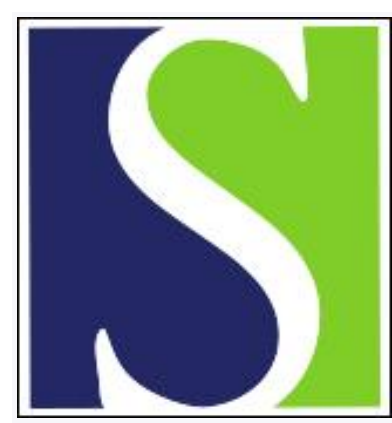

Scand J Work Environ Health 2006;32(1):41-50

https://doi.org/10.5271/sjweh.975

Issue date: 31 Feb 2006

Genital malformations in newborns of female nickel-refinery workers

by Vaktskjold A, Talykova LV, Chashchin VP, Nieboer E, Thomassen Y, Odland $џ$

Affiliation: Institutt for samfunnsmedisin, Universitetet i Tromsø, N-9037 Tromsø, Norway. arild.vaktskjold@ism.uit.no

Key terms: cryptorchidism; female; genital malformation; hypospadias; newborn; nickel; nickel-refinery worker; occupational exposure; registry; Russia

This article in PubMed: www.ncbi.nlm.nih.gov/pubmed/16539171

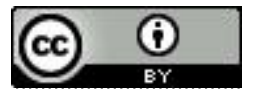




\title{
Genital malformations in newborns of female nickel-refinery workers
}

\author{
by Arild Vaktskjold, DrSc, ${ }^{1}$ Ljudmila Vasiljevna Talykova, MD, ${ }^{1,2}$ Valerij Petrovitsj Chashchin, DrMedSc, ${ }^{2,4}$ \\ Evert Nieboer, PhD, ${ }^{1,3}$ Yngvar Thomassen, ${ }^{5}$ Jon Øyvind Odland, DrMedSc ${ }^{1}$
}

\begin{abstract}
Vaktskjold A, Talykova LV, Chashchin VP, Nieboer E, Thomassen Y, Odland JØ. Genital malformations in newborns of female nickel-refinery workers. Scand J Work Environ Health 2006;32(1):41-50.

Objectives This study investigated whether pregnant women employed in nickel-exposed work areas are at elevated risk of delivering a newborn with a genital malformation.

Methods In this register-based cohort study, data about pregnancy outcome and occupation were obtained using the Kola Birth Registry. Each record in the Registry was assigned a categorical nickel exposure rating according to the occupation the delivering woman had at the time of becoming pregnant, using, as guidelines, the water-soluble nickel subfraction of the inhalable aerosol fraction obtained by personal monitoring for nickelrefinery workers or the measured urinary nickel concentrations. The reference population comprised delivering women from Mončegorsk with a background exposure level. The association of the outcome with the assigned exposure ratings was analyzed in a logistic regression model, adjusted for parity, maternal malformation, exposure to solvents, and infection in early pregnancy.

Results The odds ratio for nickel-exposed women delivering a newborn with a genital malformation was 0.81 [95\% confidence interval (95\% CI) 0.52-1.26], and that for an undescended testicle was 0.76 (95\% CI 0.40-1.47). Conclusions In this study no negative effect of maternal exposure to water-soluble nickel was found on the risk of delivering a newborn with malformations of the genital organs. The results should be interpreted with caution since there were few cases in the higher exposure groups. The findings do not exclude the possibility of an effect on the risk of other congenital malformations and adverse outcomes (including reduced fertility).
\end{abstract}

Key terms cryptorchidism; hypospadias; nickel; occupational exposure; registry; Russia.

Chashschin et al (1) were the first to report concern about an increased risk of spontaneous abortions and structural malformations in newborns among female nickel-refinery workers. The investigation had some shortcomings $(1,2)$, did not address specific malformations, and thus warranted closer scrutiny. The number of women employed in nickel refineries is large enough for epidemiologic investigations of pregnancy outcome only in Russia. In 1997, a full epidemiologic study focusing on nickel-refinery workers in the Russian borough of Mončegorsk was found feasible (2), and a birth registry was established for this purpose (3). Thorough assessments of exposure to nickel, cobalt, and other industrial hazards have also been carried out at this facility (4-6).

Water soluble nickel salts have recently been classified, on the basis of developmental effects in animal studies, as category 2 reproductive toxicants, as defined by the European Commission $(7,8)$. A developmental concern is plausible since nickel does cross the placental barrier $(4,9,10)$, and an in vitro study suggests that nickel salts may have the potential of damaging placental tissue (11). A metal related to nickel in its production is cobalt. Concentrations of both metals in urine primarily reflect airborne exposures to water-soluble nickel and divalent (II) cobalt salts $(5,12)$. Although there is no human evidence concerning cobalt in terms of fertility and development, oral and inhalation animal studies with water-soluble cobalt (II) salts suggest that they are of concern $(13,14)$.

Undescended testes and hypospadias (the urethral opening is not at the tip of the penis) are among the most frequent birth defects in boys (15). Other and more infrequent malformations of the genital organs involve the

1 Institutt for samfunnsmedisin, Universitetet i Troms $\emptyset$, N-9037 Troms $\emptyset$, Norway.

2 Kola Research Laboratory for Occupational Health, Kirovsk, Russia.

3 McMaster University, Hamilton Ontario, Canada.

$4 \quad$ Northwest Public Health Research Centre, St Petersburg, Russia.

5 The National Institute of Occupational Health, Oslo, Norway.

Correspondence to: A Vaktskjold, Institutt for samfunnsmedisin, Universitetet i Troms $\emptyset$, N-9037 Troms $\emptyset$, Norway. [E-mail: arild.vaktskjold@ism.uit.no] 
ovaries, fallopian tubes, and broad ligaments, the uterus and cervix, and indeterminate gender (16). Up to $5.9 \%$ of boys are born with at least one undescended testis $(17,18)$. Most of the cases would achieve spontaneous descent by 1 year of age $(17,19)$, but $1-4 \%$ of newborn boys in western countries are operated on for at least one undescended testis (20-22). The causes of undescended testes are believed to be multifactorial (19, 23). Undescended testes have been found in association with parity, abnormalities of external genitals, other malformations, and a family history of undescended testes $(17,24-26)$. Newborns with undescended testes appear to be at elevated risk for testicular tumors and infertility or subfertility $(27,28)$ and to have a concurrent outcome of low birthweight and prematurity $(17,20,25$, 29,30 ).

The cause of hypospadias is uncertain $(31,32)$, but a family history of hypospadias or other malformations appears to elevate the risk $(24,32-34)$. There is also an associated risk of being born small for gestational age $(29,30)$. Undescended testes and hypospadias partly appear to have similar risk profiles $(24,29)$ and tend to co-occur in newborn $(24,35)$. But in a study involving brothers (24), the presence of one of the malformations was not found to increase the risk of the other. The authors postulated that co-occurrence may be due to common environmental factors rather than to genetic factors.

Our aim in the present investigation was to assess whether pregnant women employed in the various departments of a nickel refinery were at higher risk of delivering a newborn with malformed genital organs than those not so employed in the borough of Mončegorsk. Quantitative air and urine measurements of nickel and other metals and metalloids taken during the observation period (1996-2001) have been used to characterize exposure.

\section{Study population and methods}

\section{Context}

The borough (city) of Mončegorsk is located in the Kola Peninsula in northwest Russia (3). The population (66 200 in 1995) has been exposed to large emissions of sulfur dioxide, dust, nickel, and copper from the local nickel refinery (36), which is located about 2 kilometers southwest of the city. In the period 1973-1997, the nickel company employed 9016 (42.5\%) of the delivering women from the borough (37). The refinery began operation in 1938, runs 24 hours a day, and has three workshifts. During the period 1987-1990, the workshift duration in the production units changed from
6 to 8 hours, but remained at 40 hours weekly. The refining processes in the various departments of the nickel-refinery complex have been described previously (5, $6)$.

Prenatal care in Russia is without service fees. All pregnant women are advised to visit a gynecologist before 12 weeks of pregnancy. Women having heavy or risk-related work are to be transferred to another task at their workplace as soon as a pregnancy has been confirmed (Vojtov, personal communication 2002). By law, pregnant women are obliged to leave work after 30 weeks of pregnancy. A woman can choose to have an abortion until and including week 12 of gestation. In addition to medical reasons, since 1991, induced abortion has been allowed from the 13th to the 22nd week providing there are valid social reasons for it. Hormone therapy to induce pregnancy was not available in the Kola Peninsula until a few years ago. The maternal care and maternal benefits, as well as the regulations for induced abortion in Russia, have been described earlier in some detail (3).

\section{Kola Birth Registry}

The source of the data of this investigation was the Kola Birth Registry. The Registry includes extensive data about more than $98 \%$ of all live births, as well as stillbirths of at least 28 weeks of gestation, by residents of Mončegorsk giving birth in the period March 1973 through 2001 (3). We have previously described the definitions used for a live birth, stillbirth, and spontaneous abortions in Russia and have also provided a comprehensive account of the history, content, data collection, and data quality of the Registry $(3,37)$.

The registration of congenital malformations and deformations (for brevity, these terms are hereafter referred to as "malformations") in the Registry includes up to five diagnoses per newborn. Both the code of the International Classification of Diseases, 10th revision (ICD-10), and the diagnosis spelled out in words are registered in adjacent fields. The diagnoses were entered in the order they were cited in the delivery records. In a separate field, it was depicted by "yes" or "no" whether a recorded diagnosis was uncertain.

Information about the delivering women's job functions and her employer at the onset of pregnancy was registered with a numerical code, as well as with a precise word descriptor. The employment distribution of the delivering population in Mončegorsk has been previously described in detail (37). The Kola Birth Registry has recently been updated with data about deliveries and newborns for the years 1998-2001 inclusive, and information about exposure to water-soluble nickel compounds and solvents according to occupation has been added for all delivering women. 


\section{Exposure classification and analysis details}

Summary details of the exposure matrix are provided in tables 1 and 2. Detailed in-plant exposure assessments were completed in the period 1995-2001 for the Mončegorsk secondary refining processes $(5,6)$. Since primary refining was discontinued at Mončegorsk in 1996-

Table 1. Guidelines for the assignment of categorical worker-exposure ratings in the different departments. $(P=$ primary refining; $\mathrm{S}=$ secondary refining)

\begin{tabular}{|c|c|c|c|}
\hline $\begin{array}{l}\text { Department of employment at the Mončegorsk } \\
\text { refinery complex }\end{array}$ & $\begin{array}{l}\text { Exposure } \\
\text { (general) }\end{array}$ & $\begin{array}{l}\text { Exposure } \\
\text { ratings }\end{array}$ & General description \\
\hline Control, research and technical departments a & $\begin{array}{l}\text { Background } \\
\text { to high }\end{array}$ & $0-2$ & $\begin{array}{l}0 \text { if only working inside department, } 1 \text { if visiting primary refinery, } \\
2 \text { if visiting secondary refinery }{ }^{b}\end{array}$ \\
\hline Construction, repairs, supply and service departments ${ }^{c}$ & $\begin{array}{l}\text { Background } \\
\text { to low }\end{array}$ & $0-1$ & $\begin{array}{l}0 \text { if only working inside department or outside the refinery } \\
\text { complex, } 1 \text { if occasional work in production facilities }\end{array}$ \\
\hline Sulfuric acid production & Background & 0 & \\
\hline $\begin{array}{l}\text { Copper refinery }(S) \\
\text { Matte converting }(P) \\
\text { Beneficiation }(P) \\
\text { Ore roasting }(P) \\
\text { Ore smelting }(P) \\
\text { Matte separation }(S)\end{array}$ & Low & 1 & $\begin{array}{l}\text { Periodically low exposure or continuous moderately low (as } \\
\text { opposed to background) exposure or in enclosed office in } \\
\text { production facility }\end{array}$ \\
\hline $\begin{array}{l}\text { Anode casting }(\mathrm{S}) \\
\text { Electro refinery }(\mathrm{S}) \\
\text { Matte roasting (S) } \\
\text { Nickel carbonyl plant (S) }\end{array}$ & High & $1-2$ & 2 if in plant, 1 if in enclosed space in production facility \\
\hline
\end{tabular}

Table 2. Inhalable aerosol and urinary concentrations of nickel and cobalt by department. ${ }^{\mathrm{a}}(\mathrm{GM}=$ geometric mean, $95 \% \mathrm{Cl}=95 \%$ confidence interval, $\mathrm{P}=$ primary refining, $\mathrm{S}=$ secondary refining)

\begin{tabular}{|c|c|c|c|c|c|c|c|c|}
\hline \multirow[t]{3}{*}{ Department at the Mončegorsk refinery complex } & \multicolumn{4}{|c|}{$\begin{array}{l}\text { Water-soluble subfraction of the } \\
\text { inhalable aerosol fraction }\left(\mu \mathrm{g} / \mathrm{m}^{3}\right)\end{array}$} & \multicolumn{4}{|c|}{ Urinary concentrations $(\mu \mathrm{g} / \mathrm{l})^{\mathrm{b}}$} \\
\hline & \multicolumn{2}{|c|}{ Nickel } & \multicolumn{2}{|c|}{ Cobalt } & \multicolumn{2}{|c|}{ Nickel } & \multicolumn{2}{|c|}{ Cobalt } \\
\hline & GM & $95 \% \mathrm{Cl}$ & GM & $95 \% \mathrm{Cl}$ & GM & $95 \% \mathrm{Cl}$ & GM & $95 \% \mathrm{Cl}$ \\
\hline Background &.. & .. & .. & .. & $5.9^{c}$ & $4.7-7.0^{c}$ & .. & .. \\
\hline Control, research and technical departments &.$\cdot$ & .. & .. & .. & .. & .. & .. & .. \\
\hline Construction, repairs, supply and service departments &.. & .. & .. & .. &.. & .. & .. & .. \\
\hline Sulfuric acid production &.. & .. & .. & .. & 6.3 & $4.8-8.4$ & .. & .. \\
\hline Copper electrorefining (S) & $14^{\mathrm{d}}$ & $12-17^{d}$ & $0.1^{\mathrm{d}}$ & $0.1-0.1^{\mathrm{d}}$ & 15 & $12-18$ & 0.59 & $0.5-0.7$ \\
\hline Copper pyrometallurgical (S) & $14^{\mathrm{d}}$ & $10-18^{d}$ & $0.5^{\mathrm{d}}$ & $0.4-0.6^{d}$ & 8.3 & $6.9-10$ & 0.72 & $0.6-0.9$ \\
\hline Matte converting $(\mathrm{P})$ & 24 & $12-46$ & 0.6 & $0.3-1.1$ & 20 & $13-32$ & 0.48 & $0.3-0.7$ \\
\hline Beneficiation $(\mathrm{P})$ & 3.0 & $2.0-5.0$ & 0.1 & $0.1-0.2$ & 5.1 & $3.9-6.6$ & 0.36 & $0.3-0.5$ \\
\hline Ore roasting $(P)$ & 18 & $14-24$ & 0.6 & $0.4-0.8$ & 11 & $8.5-14$ & 0.62 & $0.5-0.8$ \\
\hline Ore smelting $(\mathrm{P})$ & 62 & $42-92$ & 1.9 & $1.2-3.1$ & 20 & $16-26$ & 1.0 & $0.8-1.2$ \\
\hline Matte separation (S) & 84 & $56-120$ & 4.1 & $2.7-6.1$ & 29 & $21-41$ & 1.8 & $1.3-2.6$ \\
\hline Anode casting, old (S) & $250^{e}$ & $180-350$ e &..${ }^{\dagger}$ &..${ }^{\dagger}$ & $159^{g}$ & $122-208^{g}$ & $5.7^{g}$ & $4.4-7.4^{9}$ \\
\hline Anode casting, new (S) & $150 \mathrm{e}$ & $90-240$ e &..${ }^{\dagger}$ &..+ & $131^{g}$ & $92-186$ g & $6.1^{g}$ & $4.6-8.2^{9}$ \\
\hline Electro refinery, old (S) & $210^{e}$ & $170-260^{e}$ & .. &.. & $179 \mathrm{~g}$ & $140-230^{g}$ & $1.6^{g}$ & $1.2-2.1^{g}$ \\
\hline Electro refinery, new (S) & $225^{\mathrm{e}}$ & $150-350$ e & .. & .. & $127^{g}$ & $96-169 g$ & $1.8^{g}$ & $1.2-2.4^{g}$ \\
\hline Matte roasting (S) & $330^{e}$ & $230-450$ e &..$^{f}$ &..${ }^{\dagger}$ & $87^{g}$ & $71-106^{g}$ & $4.0^{g}$ & $3.1-5.0^{g}$ \\
\hline Nickel carbonyl plant (S) & $17^{\mathrm{h}}$ & $11-26^{h}$ & 0.6 & $0.4-1.2$ & 47 & $27-81$ & 0.7 & $0.5-1.1$ \\
\hline \multicolumn{9}{|c|}{$\begin{array}{l}\text { a Data for which no source is given are unpublished; although measured, the inhalable levels of arsenic, cadmium, and lead were minimal in all of the } \\
\text { operations surveyed [Thomassen et al, } 1999(5) ; \text { Thomassen et al, } 2004(6)] \text {. } \\
\text { b Although available, creatinine-normalized urinary concentrations do not substantially reduce the variability. } \\
\text { c From Odland et al (4); survey was conducted in 1993-1994. } \\
\text { d From Thomassen et al (6); survey was conducted in } 1996 \text {. } \\
\text { e The inhalable aerosol nickel fraction was adjusted by the subfraction of the water-soluble nickel determined in a subset of the workers monitored } \\
\text { [Thomassen et al (5)]. } \\
\text { f On the average, the cobalt air concentrations were } 1 / 50 \text { of the nickel concentrations [Thomassen et al (5)]. } \\
\text { g From Thomassen et al (5). } \\
\text { h These values do not include exposure to nickel carbonyl gas, which is readily absorbed and highly toxic. }\end{array}$} \\
\hline
\end{tabular}


1997, the corresponding processes carried out in refineries located in the northwest corner of the Kola Peninsula were surveyed in 2001. Close to 500 individual workers participated in the exposure assessment surveys (table 2). Each occupation in the Registry was assigned a categorical exposure rating to nickel by the members of the team familiar with this issue (EN, LVT, YT, VPC). This assignment was achieved by using the water-soluble subfraction of the inhalable nickel aerosol fraction and urinary nickel concentrations as guidelines for workers at the nickel-refinery complex, as well as knowledge of the refining processes and occupations. The following general categories were assigned: background exposure, low exposure, and high exposure. The category "background exposure" includes workers at the nickel refinery who work in areas with exposures estimated to be comparable to that experienced by the general population not employed at the refinery (4). The urinary nickel concentration used as a cut-off level between low and high exposure was set at about $70 \mu \mathrm{g} / \mathrm{l}$, corresponding roughly as expected $(5,38)$ to $160 \mu \mathrm{g} / \mathrm{m}^{3}$ of the water-soluble inhalable subfraction, except for the nickel tetracarbonyl workers (further details given in table 2). The assigned job-specific exposure ratings for the various job categories can be obtained from the authors.

Quarterly stationary air measurements since 1980, combined with knowledge based on company records that the refinery operations had remained materially unchanged since 1973, provide assurance that the exposure summary presented in table 2 also reflects past exposures.

The study population corresponded to all the registered deliveries (24 534 deliveries) based on the following inclusion criteria defined a priori: (i) the mother of the newborn was a resident of Mončegorsk when becoming pregnant (972 did not fulfill the criterion), (ii) the newborn's gestational age was at least 28 weeks (not met by 92 deliveries, whereof 75 were spontaneous abortions _- if the gestational age was missing, the newborn was included if weighing at least 1000 grams, (iii) the mother's workplace and job were registered (68 missing), (iv) the newborn record with information about malformations was available for registration in the Kola Birth Registry (42 missing), and (v) only one record was included if a delivery involved more than one baby (186 excluded). Thus the investigated population consisted of 23141 live- or stillborn infants. Six of the included records were missing data about gestational age when the newborn weighed at least 1000 grams. Girls comprised $48.9 \%$ and boys $51.1 \%$ of the study population. In $0.03 \%$ of the records, the information about gender was missing, or gender was indeterminate. The cases were defined as those for which the newborn was registered with an ICD-10 code denoting a malformation of the genital organs (ICD-10 Q50-Q56).
A multiple logistic-regression analysis was conducted using the presence or absence of one or more malformations of the genital organs as the dichotomous outcome. Subanalyses for undescended testes and hypospadias as outcomes, respectively, were done similarly. The factors adjusted for in the regression model were selected a priori on the basis of literature reports of relevant associations. The following were included: parity $(25,35,39)$, maternal malformation (40) (yes; no), exposure to solvents at work (41) (yes; no), and infectious disease $(39,42)$ (yes; no). Recorded occupations were used to signal solvent exposure. The presence of infection meant that the woman's medical history included one or more infectious diseases in the period from 2-3 months before pregnancy to 12 weeks of gestation or influenza during the first 12 weeks of pregnancy. Testing for syphilis and gonorrhea was carried out on all pregnant women in Mončegorsk (37). The subanalysis with undescended testes as the outcome was also adjusted for gestational age. The significance level was set at $5 \%$ in each test. The analyses were carried out using SAS statistical software 6V, version 8e (43).

The Regional Research-Ethics Board of the University of Troms $\varnothing$, the Norwegian Data Inspectorate, and the regional health administration of the Murmanskaja Oblast approved the setting up of the Kola Birth Registry and its use for epidemiologic investigations.

\section{Results}

The included newborns corresponded to deliveries by 17301 different women. As presented in table 3, 5165 $(22.3 \%)$ of the neonates were delivered by women employed within the nickel-refinery complex at the time of becoming pregnant, while an additional 4043 (17.5\%) were delivered by women employed by the refinery in workplaces located outside the plant area. The remaining delivering women were employed in other enterprises in Mončegorsk or were not employed. The proportion of women who had occupations with high and low exposure was $5.3 \%$ and $7.4 \%$, respectively. The remaining had background exposure (table 3 ).

Altogether $51 \%$ of the delivering women were nulliparous (information missing in 4 registry records). The average delivering woman was 25 (range 13-46) years of age, and her parity at delivery was 1.6 (range 1-9). Of these, 1.3 deliveries occurred while a resident of Mončegorsk at pregnancy onset and within the time frame of deliveries registered in the Kola Birth Registry. The mean age of the women delivering a newborn with malformation was 26 years. Additional maternal characteristics of the unexposed and exposed groups are presented in table 4. 
Table 3. Number of cases and the exposure ratings for the delivering women by workplace. $(95 \% \mathrm{Cl}=95 \%$ confidence interval)

\begin{tabular}{|c|c|c|c|c|c|c|c|}
\hline \multirow[t]{2}{*}{ Department at the Mončegorsk refinery complex } & \multirow{2}{*}{$\begin{array}{c}\text { Total } \\
\text { number }\end{array}$} & \multicolumn{3}{|c|}{ Exposure rating } & \multirow[t]{2}{*}{ Cases } & \multirow{2}{*}{$\begin{array}{c}\text { Rate } \\
\text { per } 1000 \\
\text { newborn }\end{array}$} & \multirow[t]{2}{*}{$95 \% \mathrm{Cl}$} \\
\hline & & 0 & 1 & 2 & & & \\
\hline Control, research and technical & 895 & 145 & 503 & 247 & 1 & . & . \\
\hline Construction, repair, supply and service departments & 2623 & 2064 & 559 a & - & 12 & 4.6 & $+/-2.6$ \\
\hline Sulfuric acid production & 14 & 14 & - & - & - & · & · \\
\hline Copper refinery & 200 & - & 200 & - & - & $\cdot$ & . \\
\hline Matte separation \& roasting & 202 & - & 76 & 126 & 1 & . & . \\
\hline Primary nickel refining unit ${ }^{b}$ & 221 & - & 221 & - & 1 & . & . \\
\hline Anode casting & 25 & - & 12 & 13 & - & . & . \\
\hline Electrorefinery ${ }^{c}$ & 958 & - & 119 & 839 & 3 & . & . \\
\hline Nickel-carbonyl plant & 27 & - & 15 & 12 & 1 & . & . \\
\hline Auxiliary services outside plant & 4043 & 4043 & - & - & 19 & 4.7 & $+/-2.0$ \\
\hline Other enterprises or unemployed & 13933 & 13933 & - & - & 65 & 4.7 & $+/-1.1$ \\
\hline Total & 23141 & 20199 & 1705 & 1237 & 103 & 4.5 & $+/-0.9$ \\
\hline
\end{tabular}

${ }^{a}$ Most are painters and plasterers

b Includes ore roasting and smelting, beneficiation, and matte converting.

c Includes the purification circuit in the nickel electrorefinery.

Table 4. Maternal characteristics for the women in the different exposure groups.

\begin{tabular}{|c|c|c|c|c|c|c|c|c|c|c|}
\hline \multirow[t]{2}{*}{ Exposure level } & \multicolumn{10}{|c|}{ Characteristic } \\
\hline & $\begin{array}{c}\text { Proportion } \\
\text { of } \\
\text { previous } \\
\text { induced } \\
\text { abortion a }\end{array}$ & $\begin{array}{l}\text { Proportion } \\
\text { of previous } \\
\text { sponta- } \\
\text { neous } \\
\text { abortion a }\end{array}$ & $\begin{array}{c}\text { Proportion } \\
\text { of } \\
\text { maternal } \\
\text { malfor- } \\
\text { mation }\end{array}$ & $\begin{array}{c}\text { Proportion } \\
\text { of } \\
\text { solvent } \\
\text { exposure }\end{array}$ & $\begin{array}{c}\text { Proportion } \\
\text { of } \\
\text { infection }\end{array}$ & $\begin{array}{l}\text { Proportion } \\
\text { of twin } \\
\text { or } \\
\text { triplet } \\
\text { delivery }\end{array}$ & $\begin{array}{l}\text { Proportion } \\
\text { of the } \\
\text { woman's } \\
\text { first } \\
\text { delivery }\end{array}$ & $\begin{array}{c}\text { Mean } \\
\text { ges- } \\
\text { tational } \\
\text { duration } \\
\text { (weeks) }\end{array}$ & $\begin{array}{c}\text { Mean } \\
\text { maternal } \\
\text { age } \\
\text { (years) }\end{array}$ & $\begin{array}{c}\text { Mean } \\
\text { deli- } \\
\text { veries } \\
\text { ex- } \\
\text { periencedb }\end{array}$ \\
\hline 0 & 40.2 & 14.2 & 1.1 & 1.5 & 3.3 & 0.80 & 51.5 & 39.4 & 25.1 & 1.64 \\
\hline 1 & 43.9 & 15.8 & 0.8 & 21.9 & 3.0 & 0.87 & 47.9 & 39.6 & 25.6 & 1.66 \\
\hline 2 & 49.5 & 17.7 & 0.6 & 0.2 & 4.0 & 0.72 & 39.7 & 39.7 & 26.4 & 1.78 \\
\hline
\end{tabular}

a It is not known which exposure groups the women belonged to at the time of their abortion.

${ }^{\mathrm{b}}$ Including the current delivery.

Altogether 103 newborns were diagnosed with one or more malformations of the genital organs -8 girls, 94 boys, and 1 of indeterminate gender. One of the cases was from a twin delivery, while four were stillborn (3.9\%). Three (2 girls) of the latter four had multiple malformations. Four diagnoses were recorded as uncertain, but were included in the study. The overall prevalence rate was 44.5/10 000 births. Four of the newborns had two malformations of the genital organs ( 3 of them had background exposure). The rate for the boys was $82.0 / 10000$, compared with 7.9/10 000 births for the girls. The department- and malformation-specific frequency and rates are summarized in tables 3 and 5, respectively. None of the registered deliveries by women from Mončegorsk that were excluded from this study resulted in a genital malformation, but $22 \%$ of them were spontaneous abortions that would not have been diagnosed.

The odds ratio (OR) of delivering a newborn with a genital malformation for the women working in nickelexposed areas was 0.81 [95\% confidence interval (95\% CI) $0.52-1.26$ ], and that for undescended testes was 0.76
Table 5. Number of malformation-specific cases in each exposure group. $(95 \% \mathrm{Cl}=95 \%$ confidence interval, ICD = International Classification of Diseases)

\begin{tabular}{|c|c|c|c|c|c|c|}
\hline \multirow[t]{2}{*}{ Outcome } & \multicolumn{4}{|c|}{ Exposure rating a } & \multirow[t]{2}{*}{ Rate $^{b}$} & \multirow[t]{2}{*}{$95 \% \mathrm{Cl}$} \\
\hline & 0 & 1 & 2 & Total & & \\
\hline Undescended testes & 49 & 3 & 2 & 54 & 2.3 & \pm 0.6 \\
\hline Hypospadias & 32 & 3 & 1 & 36 & 1.6 & \pm 0.5 \\
\hline Other genital malformation ${ }^{c}$ & 14 & 1 & 2 & 17 & 0.7 & \pm 0.3 \\
\hline Total & 95 & 7 & 5 & 107 & . & . \\
\hline Total prevalence rate/1000 & 4.7 & 4.1 & 4.0 & 4.4 & . & . \\
\hline
\end{tabular}

(95\% CI 0.40-1.47). A valid model fit was not achieved for a subanalysis with hypospadias as the outcome. Additional details about the results of the logistic regression analyses are presented in table 6 . In the pooled outcome analysis, the association of predicted probabilities 
Table 6. Adjusted odds ratios (OR) and Wald confidence intervals for genital malformation. ${ }^{\mathrm{a}}(95 \% \mathrm{Cl}=95 \%$ confidence interval)

\begin{tabular}{|c|c|c|c|c|c|c|}
\hline \multirow[t]{2}{*}{ Effect factor } & \multicolumn{4}{|c|}{ Pooled model } & \multicolumn{2}{|c|}{$\begin{array}{l}\text { Undescended } \\
\text { testis }\end{array}$} \\
\hline & $\mathrm{OR}$ & $95 \% \mathrm{Cl}$ & OR & $95 \% \mathrm{Cl}$ & $\mathrm{OR}$ & $95 \% \mathrm{Cl}$ \\
\hline Nickel exposure ${ }^{b}$ & 0.81 & $0.52-1.26$ & 0.82 & $0.52-1.28$ & 0.76 & $0.40-1.47$ \\
\hline $\begin{array}{l}\text { Low exposure }{ }^{c} \\
\text { High exposure }^{c}\end{array}$ & $\begin{array}{l}0.71 \\
0.72\end{array}$ & $\begin{array}{l}0.31-1.64 \\
0.26-1.95\end{array}$ & $\begin{array}{l}0.72 \\
0.74\end{array}$ & $\begin{array}{l}0.31-1.67 \\
0.27-2.01\end{array}$ & $\begin{array}{l}0.58 \\
0.72\end{array}$ & $\begin{array}{l}0.16-2.02 \\
0.17-2.96\end{array}$ \\
\hline Solvent ${ }^{b}$ & 2.21 & $0.95-5.14$ & 2.21 & $0.95-5.15$ & 2.18 & $0.66-7.15$ \\
\hline Parity b & 1.07 & $0.85-1.34$ & 1.03 & $0.82-1.29$ & 0.94 & $0.67-1.32$ \\
\hline Infection ${ }^{b}$ & 0.88 & $0.28-2.77$ & 0.87 & $0.27-2.74$ & 0.54 & $0.07-3.89$ \\
\hline $\begin{array}{l}\text { Maternal } \\
\text { malformation }{ }^{\mathrm{b}}\end{array}$ & 0.95 & $0.13-6.81$ & 0.97 & $0.13-9.96$ & 1.68 & $0.23-12.2$ \\
\hline Gestational age ${ }^{b}$ & . & . & . & . & 0.89 & $0.79-0.99$ \\
\hline $\begin{array}{l}\text { First visit to } \\
\text { gynecologist }{ }^{d}\end{array}$ & . & . & 1.02 & $0.99-1.04$ & . & . \\
\hline
\end{tabular}

a The probability of the presence of genital malformation was modeled.

${ }^{b}$ Test for trend across three exposure categories.

' Background exposure used as reference category.

${ }^{d}$ Included in the pooled model a posteriori.

for genital malformation and observed responses, denoted by gamma, was 0.27 . The result of the HosmerLemeshow goodness-of-fit test indicated that the model fit well $(\mathrm{P}=0.97)$.

\section{Discussion}

The observed malformation-specific prevalence rates for undescended testes and hypospadias were 23 and 16 per 10000 births, respectively, both of which were comparable to those in Norway (15). The rates of hypospadias worldwide, according to registry data, ranged from 3/ 10000 in Japan to 40/10 000 in Israel (44). However, it is not known to what extent national registries use the same definitions (44), and milder cases of hypospadias are often not detected during the first days of life (34). There are no established guidelines for classifying undescended testes $(28,45)$, which can vary in degree of descent. Thonneau et al (45) believe that the reported rates for undescended testes in different populations are not readily comparable since the definition for undescended testes varies.

Outcome information recorded at the time of an event is, as in this study, an advantage when compared with questionnaire and interview data. The Kola Birth Registry includes malformations identified at the maternity ward during the first week after delivery. Milder hypospadias may not be detected that early, and it is not known to us whether they would have been diagnosed as such. In the diagnoses, it was specified whether the undescended testes was ectopic or undescended uni- or bilaterally. The diagnostic criteria may also have changed over time. An early diagnosis of undescended testes may also be a limitation since a relatively large proportion descends naturally during infancy. However, the associations found in population-based studies have been comparable regardless of whether the case group was formed of infants with testes undescended at birth or infants being operated on for undescended testes $(22,24,25,29,35)$. The completeness of the case ascertainment in our study is unknown. However, there is no reason to believe that the diagnostic procedures and specifications, or an under-diagnosing or under-recording of cases in the delivery records, would have been differential between the exposed and unexposed persons. Female genital malformations are more infrequent and more difficult to diagnose at birth. A larger proportion of them may have been undetermined. However, an under-ascertainment of cases per se does not bias the effect estimate.

In our study, the cases were ascertained at birth and thus constituted the prevalence at birth. Our study addresses the risk of delivering a newborn with a genital malformation for women who work in nickel-exposed areas, but not the fetal risk of such a malformation. An assessment of incidence requires the inclusion of all conceptuses and thus consideration of fetal loss. In terms of exposure, the dose-response does not necessarily need to be expressed as an increased prevalence of malformation at birth; it may even appear on the protective side in the analysis due to an increased risk of fetal loss $(46,47)$. However, to include all conceptuses is usually not practical, and malformation research is often limited to recorded births.

The time window for an effect of exposure on the offspring may be very short. Hypospadias is presumed to develop between 8 and 14 weeks of gestation, while testicular descent appears to be multistaged, reaching completion in the third trimester $(19,23,30)$. An advantage of our study was that detailed information about the woman's occupation at the time of becoming pregnant was available and thereby not subject to recall bias, as it was recorded during the woman's first visit to the gynecologist. Another advantage was that the mothers of both the cases and the referents resided and lived in the same city environment and therefore had similar environmental background exposures. The population in Mončegorsk has also been very homogeneous both socioeconomically and ethnically. It was also advantageous that data about known relevant confounding factors were available and that the prospective nature of the recording of data registered in the registry also excluded the possibility of recall and information bias concerning these factors. Selection bias is also inconceivable, as the Registry covers the whole population of the borough, and relatively few records $(0.4 \%)$ had missing information about occupation. For the same reasons, the external validity of the results can be considered to be high. 
A shortcoming of our study, as in most studies involving exposure classification based on job function, was the potential for the misclassification of exposure. On the other hand, compared with investigations in which exposure levels are solely based on information about occupation or workplace, this study has the strength that assessments of job-related personal exposures and biological monitoring were conducted in the production departments. Urinary nickel concentration can be considered an index of fetal exposure since it is proportional to serum nickel. The water-soluble nickel aerosol subfraction is the most strongly associated with body fluid levels $(5,6,38)$. The major potential for misclassification concerns occupations with periodic or possible exposure, especially in the exposure window around conception and early pregnancy. The exposure of women with occupations involving occasional work in exposed areas can have been under- or overestimated, as information about the actual worktask and duration was not available, and hence information on the degree of presence in exposed areas. Furthermore, it is likely that some of the women in occupations with daily exposure were unexposed during parts of the exposure windows of interest (or during the whole period) due to holidays, sick leave, and the like. Women in the exposed groups who were not exposed during the biologically relevant exposure period will have diluted the effect in our study. Misclassification of job titles was not likely since the women's occupation was recorded during pregnancy.

If exposure to water-soluble nickel can induce the risk of genital malformations, misclassification could also be due to an inappropriate cut-off level when exposure is categorized according to measured exposure concentrations. If the exposure level for an effect on outcome is higher than the selected cut-off, so that the exposed categories in this study included many that were not at elevated risk, then our finding would be biased towards a nonadverse association between exposure and outcome.

It has been estimated that the half-time for the removal of relatively water-insoluble nickel compounds from nasal mucosa tissue of nickel workers and from the lungs in welders into urine is 3.5 years (48). Our data do not include information about the time frame of exposure, since the duration of employment in the occupation held at the time of becoming pregnant was not inquired about. Some women probably started their job not long before their pregnancy, while others had previously worked in exposed areas. However, cumulative exposure may not be a factor of particular concern for exposures primarily to water-soluble nickel, since the half-time of the appearance of nickel in urine and the removal from serum is about 24 hours (48). In Russia, as in the former Soviet Union, a pregnant woman with employment that can be potentially hazardous for the fetus has, by legislation, had the right to be temporarily transferred to another job. However, the transfer is not granted before it has been established by the gynecological polyclinic that she is pregnant. The mode, mean, and median of the gestational age at the first visit to the gynecologist was 8, 14, and 12 weeks, respectively. According to Dencker \& Erikson (49), the critical exposure period is likely to be before the ninth week of pregnancy. Thus it is plausible that a proportion of the included women had been transferred to an unexposed job before their fetus was in the critical period with respect to exposure, and such circumstances would bias an adverse exposure effect towards a no-effect finding in our study. To assess the possible impact, we included the gestational age at first visit to the gynecologist a posteriori in the pooled model, but it did not affect the odds ratio of the exposure variable (table 6).

A healthy worker effect is unavoidable as long as only working persons are included in one of the groups compared in a study. The proportion of women not economically employed was relatively small (11\%). In our study, a healthy-worker bias was more likely to have been pronounced in the choice of work or change of occupation. By legislation, every person has to be medically examined before he or she can start in a new job, and they do not get the job if their health is not adequate for the position. Every worker employed in an enterprise, such as the nickel refinery, is also required to be medically examined every year through the employer (50). Workers who have acquired a chronic disease, injury, or poor health were then likely to have been transferred from occupations that were hazardous or demanding physically, such as in the nickel production departments. However, the staff of the Kola Research Laboratory for Occupational Health, who since 1980 have carried out the annual health assessments of the Mončegorsk refinery workers, recommend that 10-20 women per year should change their jobs for health reasons. Such job changes have been voluntary for nonoccupational diseases. For these workers this recommendation would have meant that they were probably transferred to less hazardous or demanding departments and jobs within the refinery.

To act as a confounder, in this study a factor had to be causally associated with genital malformation and be associated with exposure to water-soluble nickel. The risk of undescended testes and hypospadias has been found to be associated with a family history of malformations $(24,26,34)$ and thus maternal malformation was adjusted for. A condition that has appeared to be closely associated with undescended testes and hypospadias is being born small for one's gestational age (SGA), and thus low birthweight $(29,30,35)$. Small for gestational age is considered to be due to impaired 
placental function $(22,25,29)$. However, it would be inappropriate to adjust for small for gestational age in the analysis if nickel exposures were a common cause, because a potential confounder must constitute an independent risk factor. Smoking was not considered a pertinent confounding factor since the associations reported have been weak $(25,29)$ and it is known that the smoking frequency among pregnant Russian women was relatively low (4). As indicated in footnote a of table 2, the inhalable aerosol fractions of arsenic, cadmium, and lead were generally at levels well below current occupational exposure levels (5), and exposure to these elements were therefore not considered to be relevant confounding factors.

In the model, we adjusted for workers (nickel refinery and nonrefinery) with a high likelihood of regular high exposure to solvents, namely, painters, plasterers, and spoolers, a total of $683(3.0 \%)$ persons. We chose not to adjust for workers in occupations with possible exposures to solvents or to other chemicals or metals that may have induced the risk, such as for welders, electricians, laboratory workers, and cleaners (42, 51, 52). The reason for this approach is the inherent potential of misclassification of exposure when classification is based on occupation alone (52). Furthermore, studies of such design have not shown clear findings of an elevated risk of malformations for the offspring of workers in these occupations $(42,45)$. But, even though an association between solvent exposure and genital malformation appeared, the confounding effect of solvent exposure is likely underadjusted for, especially in the background-exposure group. As revealed in table 4, a relatively high proportion in the low nickel-exposure group was exposed to solvents. The correlation between nickel and solvent exposure in the background and low nickel-exposure groups was 0.3 , which is considered a weak correlation. The overall intervariable correlations in the model were lower than 0.3, and the lowest tolerance level was $0.98\left(1-R^{2}\right.$, where each variable in the model was run against the others in multiple linear regression models). Thus the result of the regression analysis appears not to be distorted by co-linearity between the included factors. In support, the odds ratio for solvent exposure showed little change when background exposure was used as a reference category for low exposure to nickel in the pooled model $(2.4,95 \%$ CI $0.96-$ 5.78).

Although the Kola Birth Registry contains information about the occupation of all the women included in our study, we have very limited insight into what the occupations outside the nickel refinery involved in terms of exposures-especially 20 to 30 years ago. Any occupational exposures causing genital malformation in the unexposed group would have resulted in a shift towards a no-effect finding.
A large proportion of the delivering women in Moncegorsk were married to men working at the nickel refinery. Any impact of paternal exposure on genital malformation among the offspring would blur the findings of our study. This possibility has not been evaluated. If there was an increased risk associated with paternal exposure, one would have expected high rates of genital malformations or miscarriages. The latter has not been quantified, although the proportion of women who had experienced a previous spontaneous abortion was higher in the exposed groups (table 4).

Women who were not residents of Mončegorsk at the onset of pregnancy were not included in the study because information was not available about when they moved during pregnancy and where they had worked previously.

Our study included 5840 deliveries (25.2\%) by women who contributed more than one delivery to this study, which may violate the assumption of independent outcomes. According to Sharma (53), there are no sophisticated tests available for checking if this assumption is violated. One way to avoid this possibility is to restrict a study to first pregnancies. However, since only $50.6 \%$ the deliveries in our material were by nulliparae women, such a restriction would have had a severe impact on the statistical power needed to address the studied issue. Given the low number of included sibships that were affected more than once (1 sibship), the effect of dependence is likely negligible. If the independence assumption was violated, it would have required a more stringent alpha level for rejecting the null (53), so it should not have impacted the conclusion drawn in this study.

We found that maternal exposure during the periconception period and early pregnancy to water-soluble nickel (and related metals) had no adverse effect on the risk of delivering a newborn with malformations of the genital organs. However, the odds ratio reported should be interpreted with caution since there were few cases in the higher exposure groups and there is a potential bias towards a nonadverse finding. Our findings do not exclude the possibility of an effect on the risk of other congenital malformations and adverse outcomes (including reduced fertility). Studies to address this possibility are warranted.

\section{Acknowledgments}

The Mončegorsk Municipal Environment Fund and the Norwegian Foreign Ministry equally sponsored the initial set up of the Kola Birth Registry. The study and the ongoing work at the registry was sponsored by the Norwegian Ministry of Health, through the Barents Health 
Programme, the Nickel Producers Environmental Research Association (Durham, NC), the Ontario (Canada) Workplace Safety and Insurance Board, and the Norwegian Research Council.

The authors thank Aleksandr Vojtov, head doctor at the gynecological polyclinic in Mončegorsk, the staff at the Kola Research Laboratory for Occupational Health in Kirovsk, and Severonikel.

\section{References}

1. Chashschin VP, Artunina GP, Norseth T. Congenital-defects, abortion and other health-effects in nickel refinery workers. Sci Total Environ. 1994;148(2-3):287-91.

2. Odland JO, Tchachtchine VP, Bykov V, Fiskebeck PE, Lund E, Thomassen Y, et al. Critical evaluation of medical, statistical, and occupational data sources in the Kola Peninsula of Russia pertinent to reproductive health studies. Int Arch Occup Environ Health. 1999;72(3):151-60.

3. Vaktskjold A, Talykova L, Chashchin V, Nieboer E, Odland JØ. The Kola Birth Registry and perinatal mortality in Montsjegorsk, Russia. Acta Obstet Gynecol Scand. 2004; 83(1):58-69.

4. Odland JO, Nieboer E, Romanova N, Thomassen Y, Norseth $\mathrm{T}$, Lund E. Urinary nickel concentrations and selected pregnancy outcomes in delivering women and their newborns among arctic populations of Norway and Russia. J Environ Monit. 1999;1(2):153-61.

5. Thomassen Y, Nieboer E, Ellingsen D, Hetland S, Norseth T, Odland JO, et al. Characterisation of workers' exposure in a Russian nickel refinery. J Environ Monit. 1999;1(1):15-22.

6. Thomassen Y, Nieboer E, Romanova N, Nikanov A, Hetland $\mathrm{S}$, VanSpronsen EP, et al. Multi-component assessment of worker exposures in a copper refinery. part 1: environmental monitoring. J Environ Monit. 2004;6(12):985-91.

7. Committee for Compounds Toxic to Reproduction. Nickel and its compounds; evaluation of the effects on reproduction, recommendation for classification. The Hague: Health Council of the Netherlands; 2003. Publication no 2.

8. The European Commission. Commission directive 93/21/EEC of 27 April 1993 adapting to technical progress for the 18th time Council Directive 67/548/EEC on the approximation of the laws, regulations and administrative provisions relating to the classification, packaging and labelling of dangerous substances. The European Commission; 1993. Available from: http://europa.eu.int/eur-1ex/lex/LexUriServ/ LexUriServ.do?uri=CELEX:31993L0021:EN:HTML

9. Sunderman FW Jr. A review of the metabolism and toxicology of nickel. Ann Clin Lab Sci. 1977;7(5):377-98.

10. Clarkson TW, Nordberg GF, Sager PR. Reproductive and developmental toxicity of metals. Scand J Work Environ Health. 1985;11:145-54.

11. Chen CY, Lin TH. Nickel toxicity to human term placenta: in vitro study on lipid peroxidation. J Toxicol Environ Health A. 1998;54(1):37-47.

12. Sunderman FW Jr. Biological monitoring of nickel in humans. Scand J Work Environ Health. 1993;19 suppl 1:34-8.

13. Agency for Toxic Substances and Disease Registry (ATSDR). Draft toxicological profile for cobalt. Atlanta (GA): ATSDR, US Department of Health and Human Services; 2001.
14. Midtgard U, Binderup ML. Cobalt and cobalt compounds. Solna (Sweden): Arbetslivsinstitutet; 1994. Arbete och Hälsa 114. p 39.

15. Medisinsk fødselsregister [Medical Birth Registry of Norway]. Fødsler i Norge, årsmelding 1999 og 2000 [Births in Norway, Annual Report 1999 and 2000]. Oslo: Nasjonalt folkehelseinstitutt; 2002.

16. Kallin L, editor. ICD-9-CM congenital abnormalities. Umeå (Sweden): Umeå universitet; 2004. Available from: http:// www.cs.umu.se/ medinfo/ICD9/icd9cm_group14.html.

17. Thong M, Lim C, Fatimah H. Undescended testes: incidence in 1,002 consecutive male infants and outcome at 1 year of age. Pediatr Surg Int. 1998;13(1):37-41.

18. Jackson MB. The epidemiology of cryptorchidism. Horm Res. 1988;30(4-5):153-6.

19. Hutson JM, Hasthorpe S, Heyns CF. Anatomical and functional aspects of testicular descent and cryptorchidism. Endocr Rev. 1997;18(2):259-80.

20. John Radcliffe Hospital Cryptorchidism Study Group. Cryptorchidism: a prospective study of 7500 consecutive male births, 1984-8. Arch Dis Child. 1992;67(7):892-9.

21. Barthold JS, Gonzalez R. The epidemiology of congenital cryptorchidism, testicular ascent and orchiopexy. J Urol. 2003;170(6):2396-401.

22. Jones ME, Swerdlow AJ, Griffith M, Goldacre MJ. Prenatal risk factors for cryptorchidism: a record linkage study. Paediatr Perinat Epidemiol. 1998;12(4):383-96.

23. Ivell R, Hartung $\mathrm{S}$. The molecular basis of cryptorchidism. Mol Hum Reprod. 2003;9(4):175-81.

24. Weidner IS, Moller H, Jensen TK, Skakkebaek NE. Risk factors for cryptorchidism and hypospadias. J Urol. 1999;161(5):1606-9.

25. Biggs ML, Baer A, Critchlow CW. Maternal, delivery, and perinatal characteristics associated with cryptorchidism: a population-based case-control study among births in Washington State. Epidemiology. 2002;13(2):197-204.

26. Berkowitz GS, Lapinski RH. Risk factors for cryptorchidism: a nested case-control study. Paediatr Perinat Epidemiol. 1996;10(1):39-51.

27. Rozanski TA, Bloom DA. The undescended testis: theory and management. Urol Clin North Am. 1995;22(1):107-18.

28. Stang A, Ahrens W, Bromen K, Baumgardt-Elms C, Jahn I, Stegmaier C, et al. Undescended testis and the risk of testicular cancer: importance of source and classification of exposure information. Int J Epidemiol. 2001;30(5):1050-6.

29. Akre O, Lipworth L, Cnattingius S, Sparen P, Ekbom A. Risk factor patterns for cryptorchidism and hypospadias. Epidemiology. 1999;10(4):364-9.

30. Moller H, Weidner IS. Epidemiology of cryptorchidism and hypospadias. Epidemiology. 1999;10(4):352-4.

31. Hussain N, Chaghtai A, Herndon CDA, Herson VC, Rosenkrantz TS, McKenna PH. Hypospadias and early gestation growth restriction in infants. Pediatrics. 2002;109(3):473-8.

32. Kallen B, Bertollini R, Castilla E, Czeizel A, Knudsen LB, Martinez-Frias ML, et al. A joint international study on the epidemiology of hypospadias. Acta Paediatr Scand Suppl. 1986;324:1-52.

33. Stoll C, Alembik Y, Roth MP, Dott B. Genetic and environmental-factors in hypospadias. J Med Genet. 1990;27(9):55963.

34. Fredell L, Kockum I, Hansson E, Holmner S, Lundquist L, Lackgren G, et al. Heredity of hypospadias and the significance of low birth weight. J Urol. 2002;167(3):1423-7.

35. Hjertkvist M, Damber JE, Bergh A. Cryptorchidism: a regis- 
try based study in Sweden on some factors of possible aetiological importance. J Epidemiol Community Health. 1989;43(4):324-9.

36. Norseth T. Environmental pollution around nickel smelters in the Kola Peninsula (Russia). Sci Total Environ. 1994;148(23):103-8.

37. Vaktskjold A, Paulsen EA, Talykova TV, Nieboer E, Odland JO. The prevalence of selected pregnancy outcome risk factors in the life-style and medical history of the delivering population in north-western Russia. Int J Circumpolar Health. 2004;63(1):39-60.

38. Nieboer E, Sanford WE, Stace BC. Absorption, distribution and excretion of nickel. In: Nieboer E, Nriagu JO, editors. Nickel and human health: current perspectives, advances in environmental science and technology. New York (NY): John Wiley \& Sons; 1992. p 49-68.

39. Wang J, Wang B. Study on risk factors of cryptorchidism. Zhonghua Liu Xing Bing Xue Za Zhi. 2002;23(3):190-3.

40. Skjaerven R, Wilcox AJ, Lie RT. A population-based study of survival and childbearing among female subjects with birth defects and the risk of recurrence in their children. N Engl J Med. 1999;340(14):1057-62.

41. McMartin KI, Chu M, Kopecky E, Einarson TR, Koren G. Pregnancy outcome following maternal organic solvent exposure: a meta-analysis of epidemiologic studies. Am J Ind Med. 1998;34(3):288-92.

42. Taskinen HK. Effects of parental occupational exposures on spontaneous abortion and congenital malformation [review]. Scand J Work Environ Health. 1990;16(5):297-314.

43. SAS [computer program]. Version 8.2. Cary (NC): SAS Institute Inc; 2004.

44. Paulozzi LJ. International trends in rates of hypospadias and cryptorchidism. Environ Health Perspect. 1999;107(4):297-
302.

45. Thonneau PE, Candia P, Mieusset R. Cryptorchildism: incidence, risk factors, and potential role of environment; an update. J Androl. 2003;24(2):155-62.

46. Selevan SG, Lemasters GK. The dose-response fallacy in human reproductive studies of toxic exposures. J Occup Med. 1987;29(5):451-4.

47. Miller JR, Poland BJ. The value of human abortuses in the surveillance of developmental anomalies, I: general overview. Can Med Assoc J. 1970;103(5):501-2.

48. Nieboer E, Fletcher GG, Thomassen Y. Relevance of reactivity determinants to exposure assessment and biological monitoring of the elements. J Environ Monit. 1999;1(1):1-14.

49. Dencker L, Eriksson P. Susceptibility in utero and upon neonatal exposure. Food Addit Contam. 1998;15 suppl:37-43.

50. Ministerstv0 Zdravoochranenie Rossijskoj federatsii (The Russian Ministry of Health). Prikaz no 90 [Legislative order no 90, in Russian]. Moscow: Ministerstvo Zdravoochranenie Rossijskoj federatsii; 1990.

51. Khattak S, Moghtader G, McMartin K, Barrera M, Kennedy D, Koren G. Pregnancy outcome following gestational exposure to organic solvents: a prospective controlled study. JAMA. 1999;281(12):1106-9.

52. van Tongeren M, Nieuwenhuijsen MJ, Gardiner K, Armstrong B, Vrijheid M, Dolk H, et al. A job-exposure matrix for potential endocrine-disrupting chemicals developed for a study into the association between maternal occupational exposure and hypospadias. Ann Occup Hyg. 2002;46(5):465-77.

53. Sharma S. Independence of observations. In: Kent T, Dellers $\mathrm{P}$, editors. Applied multivariate techniques.Toronto $(\mathrm{ON})$ : John Wiley; 1996. p 387-8.

Received for publication: 22 December 2004 